The Effect of Word of Mouth on Purchase Intention with Brand Image as a Mediation Variable (Survey of Surakarta Gacoan Noodle Consumers

\title{
Pengaruh Word Of Mouth Terhadap Purchase Intention Dengan Brand Image Sebagai Variabel Mediasi (Survey Pada Konsumen Mie Gacoan Surakarta)
}

Edi Wibowo ${ }^{1}$, Setyaningsih $\mathrm{SU}^{2}$

${ }^{1,2)}$ Fakultas Ekonomi Universitas Slamet Riyadi Surakarta,

E-mail: ediwibowo58@gmail.com¹; u.setya@yahoo.co.id ${ }^{2}$

\begin{abstract}
This research aims to (1) analyze effect of WOM on purchase intention; (2) analyze effect of WOM on purchace intention; (3) analyze effect of brand image on purchace intention; (4) analyze effect of WOM on purchace intention mediates of brand image. Population were all consumer of the Mie Gacoan Surakarta. Sample constist of 100 respondent taking on accidental sampling technique. Data collecting technique using questionnaire. Data analysis using path analyze and Sobel test. Result of this study (1) WOM have significance effect on brand image. (2) WOM have significance effect on purchase intention. (3) Brand image have significance effect on purchase intention. (4) WOM have significance effect on purchase intention mediates of brand image.
\end{abstract}

Keyword :WOM, brand image, purchase intention

Abstrak

Penelitian ini bertujuan (1) menganalisis pengaruh WOM terhadap brand image; (2) menganalisis pengaruh WOM terhadap purchace intention; (3) pengaruh brand image terhadap purchace intention; (4) menganalisis pengaruh WOM terhadap purchace intention yang dimediasi brand image. Populasi adalah seluruh konsumen Mie Gacoan Surakarta. Jumlah sampel 100 responden yang diambil dengan teknik accidental sampling. Teknik pengumpulan data menggunakan kuesioner. Analisis data menggunakan analisis jalur dan uji Sobel. Hasil penelitian menunjukkan bahwa (1) WOM berpengaruh signifikan terhadap brand image. (2) WOM berpengaruh signifikan terhadap purchase intention. (3) Brand image berpengaruh signifikan terhadap purchase intention. (4) WOM berpengaruh signifikan terhadap purchase intention yang dimediasi brand image.

Keyword :WOM, brand image, niat pembelian

\section{PENDAHULUAN}

Menjamurnya bisnis kuliner di kota Surakarta merupakan fenomena menarik untuk diteliti. Mie Gacoan Solo salah satu usaha franchise yang sukses, setiap hari selalu ramai dikunjungi konsumen. Hasil pengamatan peneliti, Mie Gacoan memiliki kreativitas dan inovasi produk sehingga dapat mendorong minat beli konsumen.

Purchase intention atau minat beli diartikan sesuatu hal yang dapat merefleksikan rencana pembelian dari sejumlah produk dengan merek tertentu (Dewi \& Ardani, 2018). Minat beli adalah salah satu variabel outcome yang paling popular dalam komunikasi e-WOM (Sher \& Lee, 2009). Sikap konsumen menjadi suka atau tidak suka tergantung dari ulasan online yang bersifat positif atau negatif (Lee et al., 2008). Rekomendasi konsumen secara positif diasosiasikan dengan niat membeli dan dengan dampak yang berbanding lurus terhadap pilihan konsumen (Chang \& Chin, 2010).

Word of mouth adalah salah satu anteseden dari minat beli konsumen, ulasan dan komentar dari konsumen sangat penting bagi pemasar. Hasil riset sebelumnya yang dilakukan Jalilvand (2012), Khan (2015), Aditya \& Wardana (2017), Akbar \& Rosita (2017); Khan et al. (2015); Tien (2018); Dewi \& Ardani (2018) menyatakan bahwa WOM memiliki hubungan positif dan signifikan terhadap minat beli.

WOM merupakan konsep penting karena diyakini sebagai salah satu saluran komunikasi yang paling kuat, dengan dampak potensial lebih pada konsumen daripada iklan tradisional WOM positif akan berdampak pada keputusan pembelian dan orang cenderung mengikuti rekomendasi keluarga, teman, dan kolega mereka (Bansal \& Voyer, 2000; Valle et al., 2006; Murphy et al., 2007; Fakharyan et al., 2012).

Hasil penelitian lain menunjukkan brand image adalah anteseden dari purchace intention, citra merek dari suatu produk atau jasa dapat mempengaruhi minat konsumen untuk membeli. Konsumen akan lebih berminat membeli produk atau jasa yang memiliki citra merek yang baik. Hal ini didukung riset yang dilakukan Torlak et al. (2014); Yunus et al. (2016); Dewi \& Ardani (2018); Andrew (2019) 
bahwa brand image berpengaruh positif dan signfikan terhadap purchace intention.

Dalam beberapa penelitian memperoleh temuan bahwa WOM dapat mempengaruhi purchace intention melalui brand image. Hasil penelitian Dewi \& Ardani (2018); Torlak et al. (2014) dan Yunus et al. (2016) menunjukkan bahwa brand image memediasi pengaruh e-WOM terhadap purchase intention.

Permasalahan, sampai saat ini belum ditemukan penelitian yang menganalisis peran brand image dalam memediasi pengaruh word of mouth terhadap purchase intention dalam pembelian produk Mie Gacoan di Surakarta. Berdasarkan latar belakang yang penulis kemukakan diatas, perumusan masalah dalam penelitian ini (1) Apakah WOM berpengaruh signifikan terhadap purchase intention pada konsumen Mie Gacoan Surakarta. (2) Apakah WOM berpengaruh signifikan terhadap brand image pada konsumen Mie Gacoan Surakarta. (3) Apakah brand image berpengaruh signifikan terhadap purchase intention pada konsumen Mie Gacoan Surakarta. (4) Apakah WOM berpengaruh terhadap purchase intention dengan dimediasi brand image pada konsumen Mie Gacoan Surakarta.

Tujuan dari penelitian ini (1) untuk menganalisis pengaruh WOM terhadap purchase intention pada konsumen Mie Gacoan Surakarta; (2) untuk menganalisis pengaruh WOM terhadap brand image pada konsumen Mie Gacoan Surakarta; (3) untuk menganalisis pengaruh brand image terhadap purchase intention pada konsumen Mie Gacoan Surakarta; (4) untuk menganalisis pengaruh WOM terhadap purchase intention yang dimediasi brand image pada konsumen Mie Gacoan Surakarta.

Hipotesis yang diajukan dalam penelitian (1) WOM berpengaruh signifikan terhadap purchase intention pada konsumen Mie Gacoan Surakarta. (2) WOM berpengaruh signifikan terhadap brand image pada konsumen Mie Gacoan Surakarta. (3) Brand image berpengaruh signifikan terhadap purchase intention pada konsumen Mie Gacoan Surakarta. (4) WOM berpengaruh terhadap purchase intention dengan dimediasi brand image pada konsumen Mie Gacoan Surakarta.

Luaran penelitian ini adalah artikel yang dipublikasikan pada JURNAL EKONOMI DAN KEWIRAUSAHAAN, Universitas Slamet Riyadi Surakarta.

Kontribusi penelitian adalah memberikan pemahaman teoritis, metodologis dan praktis tentang hubungan kausalitas antara WOM, brand image dengan purchase intention konsumen dalam pembelian produk Mie Gacoan di Surakarta. Penelitian ini dapat digunakan sebagai acuan dalam menetapkan kebijakan bagi marketer Mie Gacoan Surakarta dalam upaya mendorong peningkatan minat beli konsumen.

\section{METODE}

\section{Desain Penelitian}

Jenis penelitian ini adalah penelitian survey dengan menggunakan pendekatan kuantitatif. Desain/rancangan penelitian ini adalah tipe eksplanatori yaitu menjelaskan hubungan kausal antara variabel-variabel melalui pengujian hipotesis.

\section{Populasi dan Sampel}

Populasi dalam penelitian ini adalah semua konsumen yang membeli produk di rumah makan Mie Gacoan Surakarta. Ukuran populasi dalam penelitian ini sangat banyak dan tidak dapat diketahui dengan pasti, oleh karena itu besar sampel yang digunakan dihitung dengan rumus sebagai berikut:

$$
N=\left(\frac{Z^{2}}{4(M o e)^{2}}\right) \quad \text { (Nazir, 2009: 278) }
$$

Keterangan:

$\mathrm{N}=$ Ukuran sampel

$\mathrm{Z}=$ skor pada tingkat signifikan tertentu (derajat keyakinan ditentukan 90\%) maka $\mathrm{Z}=1,96$

Moe $=$ margin of error, tingkat kesalahan maksimum adalah $10 \%$

Dengan menggunakan rumus di atas, maka diperoleh perhitungan sebagai berikut:

$$
N=\left(\frac{1,96^{2}}{4(10 \%)^{2}}\right)=96
$$

Dari hasil perhitungan sampel diperoleh jumlah sampel 96, untuk memudahkan pelaksanaan penelitian maka peneliti akan menggunakan sampel 100 responden. Teknik pengambilan sampel dalam penelitian 
ini menggunakan accidental sampling.

\section{Instrumen Penelitian}

Definisi operasional dan pengukuran variabel penelitian diuraikan sebagai berikut.

\section{Word of mouth}

Word of mouth adalah pertukaran informasi dua orang atau lebih untuk membicarakan pengalamannya dalam mengkonsumsi produk Mie Gacoan Surakarta baik komunikasi face to face maupun melalui media online. Word of mouth diukur dengan dimensi yang dikembangkan oleh Dewi dan Ardani (2018) yaitu:
a. Mendengarkan hal-hal positif
b. Memperoleh rekomendasi
c. Memperoleh ajakan untuk membeli

2. Brand Image

Brand image adalah sejumlah keyakinan tentang merek Mie Gacoan yang dipresepsikan oleh konsumen. Brand image dalam penelitian ini diukur menggunakan dimensi yang dikembangkan oleh Shimp (2014: 40) yaitu:
a. Citra positif
b. Ciri khas yang berbeda
c. Dikenal masyarakat luas
d. Favorable

3. Purchase intention

Purchase intention adalah rekomendasi yang didapat konsumen melalui informasi yang diserap memiliki hubungan yang positif terhadap niat membeli produk di Mie Gacoan Surakarta. Purchase intention diukur dengan dimensi yang dikembangkan Andrew (2019) :
a. Minat transaksional
b. Minat referensial
c. Minat preferensial
d. Minat eksploratif

\section{Teknik Pengumpulan Data}

Teknik pengumpulan data menggunakan kuesioner yang diukur dengan skala Likert 5 poin yaitu Sangat Setuju (5), Setuju (4), Netral (3), Tidak Setuju (2). Sangat Tidak Setuju (1).

\section{Pengujian Data}

Untuk menguji kualitas data dilakukan uji validitas dan reliabilitas instrumen menggunakan rumus Korelasi Pearson dan Cronbach Alpha.

\section{Teknik Analisis Data}

1. Uji Asumsi Klasik

Uji Asumsi Klasik dilakukan melalui empat uji yaitu uji multikolinieritas, uji autokorelasi, uji heteroskedastisitas, dan uji normalitas.

2. Teknik analisis data

Teknik analisis data menggunakan analisis jalur bertujuan menguji pengaruh WOM terhadap purchase intention melalui brand image sebagai variabel mediasi. Langkah-langkah perhitungan analisis jalur disusun berdasarkan empat persamaan regresi sebagai berikut (Ghozali, 2005):

$\mathrm{Y}_{1}=\alpha+\mathrm{b}_{1} \mathrm{X}+\mathrm{e}_{1}$

$\mathrm{Y}_{2}=\alpha+\mathrm{b}_{2} \mathrm{X}+\mathrm{b}_{3} \mathrm{Y}_{1}+\mathrm{e}_{2}$

Keterangan:

$\mathrm{X} \quad$ : Word of mouth

$\mathrm{Y}_{1} \quad$ : Brand image

$\mathrm{Y}_{2} \quad$ : Purchase intention

$\mathrm{b}_{1} . . \mathrm{b}_{3} \quad:$ Koefisien regresi

e : error 
3. Pengujian Hipotesis

Uji pengaruh langsung menggunakan uji t dan uji pengaruh tidak langsung (pengaruh mediasi) menggunakan menggunakan Sobel Test dengan tingkat signifikansi 0,05.

\section{HASIL PENELITIAN}

Karakteristik Demografi

Karakteristik demografi responden dalam penelitian ini disajikan seperti tabel berikut.

Tabel 1. Analisis Karakteristik Demografi Responden

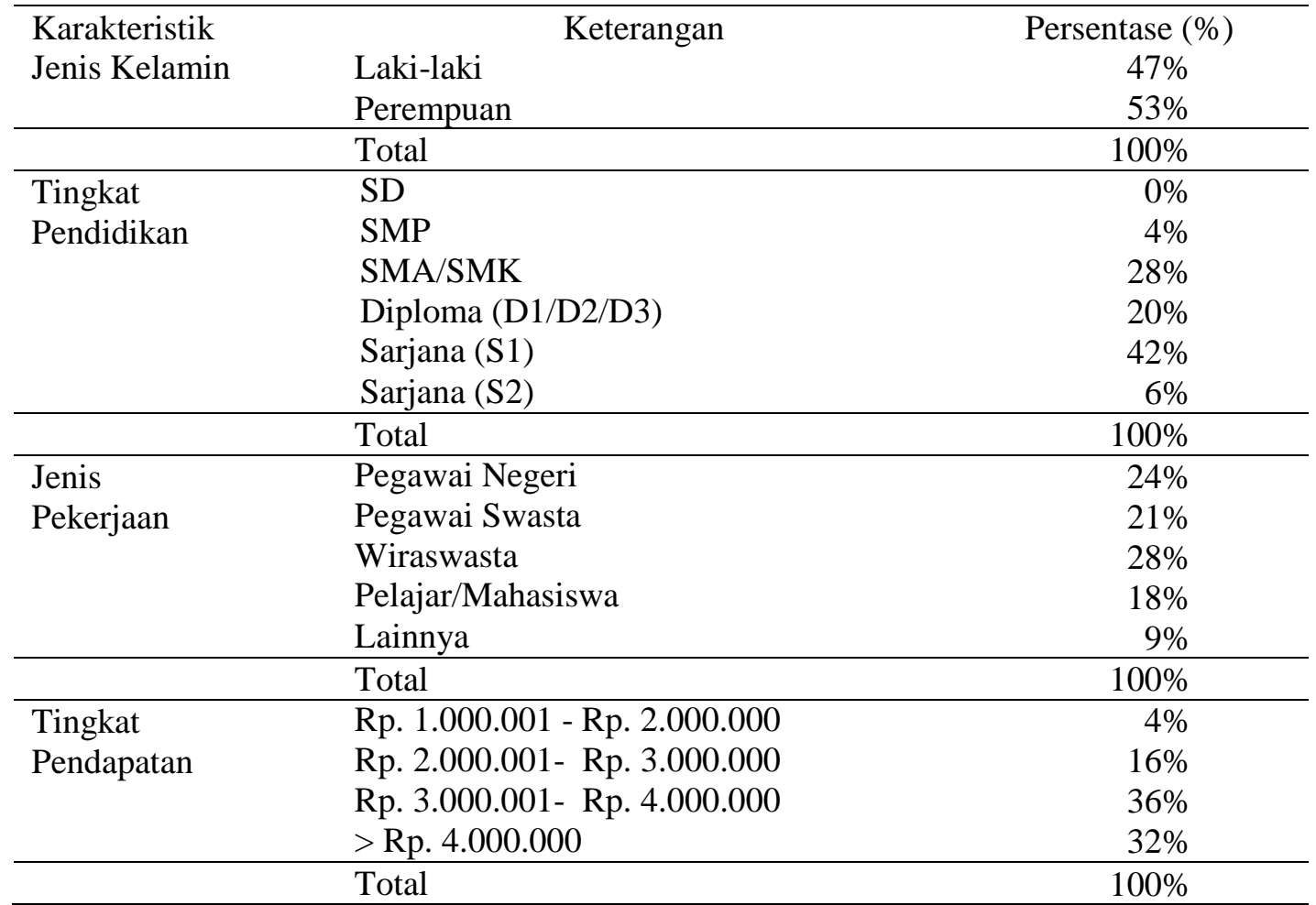

Sumber : Data primer diolah, 2020

Hasil Uji Validitas dan Reliabilitas Instrumen

Hasil uji validitas melalui uji Korelasi Pearson menunjukkan bahwa semua butir pernyataan untuk variabel WOM, brand image, purchase intention semuanya valid, ditunjukkan dengan $r$ hitung $>r$ tabel. Hasil uji validitas butir dengan program SPSS disajikan seperti tabel berikut.

Tabel 2. Hasil Uji Validitas

\begin{tabular}{cccccc}
\hline Item & \multicolumn{3}{c}{ r hitung } & r tabel & Keterangan \\
\cline { 1 - 3 } & WOM & Brand Image & Purchase Intention & & \\
\hline 1 & 0,574 & 0,700 & 0,760 & 0,195 & Valid \\
2 & 0,800 & 0,839 & 0,490 & 0,195 & Valid \\
3 & 0,723 & 0,729 & 0,692 & 0,195 & Valid \\
4 & 0,790 & 0,681 & 0,836 & 0,195 & Valid \\
5 & 0,743 & & & 0,195 & Valid \\
6 & 0,793 & & & 0,195 & Valid \\
7 & 0,794 & & & 0,195 & Valid \\
8 & 0,444 & & 0,195 & Valid \\
9 & 0,786 & & & 0,195 & Valid \\
\hline
\end{tabular}

Sumber : Data primer diolah, 2020 
Berdasarkan uji reliabilitas instrumen diperoleh hasil bahwa instrumen untuk variabel WOM, brand image, purchase intention dinyatakan reliabel karena masing-masing variabel menghasilkan Cronbach Alpha > 0,60. Berdasarkan pengolahan data dengan program SPSS berikut ini disajikan hasil uji reliabilitas untuk instrumen WOM, brand image, purchase intention.

Tabel 3. Hasil Uji Reliabilitas Instrumen

\begin{tabular}{lccc}
\hline \multicolumn{1}{c}{ Variabel } & Cronbach Alpha & Kriteria uji & Keterangan \\
\hline WOM & 0,878 & 0,60 & Reliabel \\
Brand Image & 0,720 & 0,60 & Reliabel \\
Purchase Intention & 0,667 & 0,60 & Reliabel \\
\hline
\end{tabular}

Sumber : Data primer diolah, 2020

\section{Hasil Uji Asumsi Klasik}

Berdasarkan pengolahan data dengan program SPSS berikut ini disajikan hasil uji asumsi klasik meliputi Uji multikolinieritas, uji heteroskedastisitas, uji autokorelasi, dan uji normalitas.

Tabel 4. Hasil Uji Asumsi Klasik

\begin{tabular}{|c|c|c|}
\hline Uji Asumsi Klasik & Hasil Uji & Kesimpulan \\
\hline Uji Multikolinieritas & $\begin{array}{l}\text { Tolerance }(0,789 ; 0,789)>0,1 \\
\text { VIF }(\mathbf{1}, \mathbf{2 4 3} ; \mathbf{1 , 2 4 3})<\mathbf{1 0}\end{array}$ & Tidak ada multikolinieritas \\
\hline & $P$ value $(0,317 ; 0,487)>0,05$ & Tidak \\
\hline Heter & & Heterosk \\
\hline Uji Autokorelasi & $P$ value $(1,000)>0,05$ & Tidak ada Autokorelasi \\
\hline Uji Normalitas & $P$ value $(0,918)>0,05$ & Residual normal \\
\hline
\end{tabular}

Sumber : Data primer diolah, 2020

Hasil uji asumsi klasik menunjukkan bahwa model regresi linier berganda tidak terjadi masalah multikolinieritas, tidak terjadi masalah heteroskedastisitas, tidak terjadi masalah autokorelasi, dan residual normal.

\section{Hasil Analisis Jalur}

Analisis jalur bertujuan untuk mengetahui pengaruh WOM terhadap purchase intention melalui brand image sebagai variabel mediasi.. Hasil pengujian setiap hipotesis dapat dijelaskan sebagai berikut.

1. Uji Hipotesis Pengaruh Langsung

Hasil uji pengaruh langsung disajikan seperti tabel dibawah ini.

Tabel 5. Uji Hipotesis Pengaruh Langsung

\begin{tabular}{|c|l|c|c|c|c|c|}
\hline Hipotesis & $\begin{array}{c}\text { Pengaruh } \\
\text { Langsung }\end{array}$ & $\begin{array}{c}\text { Koefisien } \\
\text { Jalur }(\beta)\end{array}$ & $\begin{array}{c}\text { Standar } \\
\text { Error }\end{array}$ & nilai t & $p$ value & Keterangan \\
\hline $\mathrm{H} 1$ & $\mathrm{X} \rightarrow \mathrm{Y} 1$ & 0,457 & 0,047 & 5,092 & 0,000 & H1 Diterima \\
\hline $\mathrm{H} 2$ & $\mathrm{X} \rightarrow \mathrm{Y} 2$ & 0,394 & 0,044 & 4,315 & 0,000 & H2 Diterima \\
\hline $\mathrm{H} 3$ & $\mathrm{Y} 1 \rightarrow \mathrm{Y} 2$ & 0,308 & 0,088 & 3,388 & 0,001 & H3 Diterima \\
\hline
\end{tabular}

Sumber : Data primer diolah, 2020

Berdasarkan hasil penelitian, pengujian hipotesis dapat dijelaskan di bawah ini.

a. Pengujian hipotesis 1

Berdasarkan hasil analisis regresi diperoleh nilai $t_{\text {hitung }}(5,092)>t_{\text {tabel }}(2,000)$ atau $p$ value $(0,000)$ $<0,05$. Berarti WOM berpengaruh signifikan terhadap brand image. Dengan demikian hipotesis 
1 yang menyatakan "Diduga WOM berpengaruh terhadap brand image pada konsumen Mie Gacoan Surakarta" diterima.

b. Pengujian Hipotesis 2

Berdasarkan hasil analisis regresi diperoleh nilai $t_{\text {hitung }}(4,315)>t_{\text {tabel }}(2,000)$ atau $p$ value $(0,000)$ $<0,05$. Berarti WOM berpengaruh signifikan terhadap purchase intention. Dengan demikian hipotesis 2 yang menyatakan "Diduga WOM berpengaruh terhadap purchase intention pada konsumen Mie Gacoan Surakarta" diterima.

c. Pengujian hipotesis 3

Berdasarkan hasil analisis regresi diperoleh nilai $t_{\text {hitung }}(3,388)>t_{\text {tabel }}(2,000)$ atau $p$ value $(0,001)$ $<0,05$. Berarti brand image berpengaruh signifikan terhadap purchase intention. Dengan demikian hipotesis 3 yang menyatakan "Diduga brand image berpengaruh terhadap purchase intention pada konsumen Mie Gacoan Surakarta" diterima.

2. Uji Hipotesis Pengaruh Mediasi

Uji pengaruh mediasi bertujuan untuk menguji posisi variabel mediasi dalam model. Pengujian pengaruh mediasi yang ada dalam hipotesis 4 menggunakan Uji Sobel. Perhitungan untuk Uji Sobel menggunakan kalkulator online (www.danielsoper.com). Pengujian hipotesis 4 bertujuan untuk menguji pengaruh tidak langsung WOM terhadap purchase intention melalui brand image. Hasil Sobel Test disajikan disajikan dalam gambar dan tabel di bawah ini.

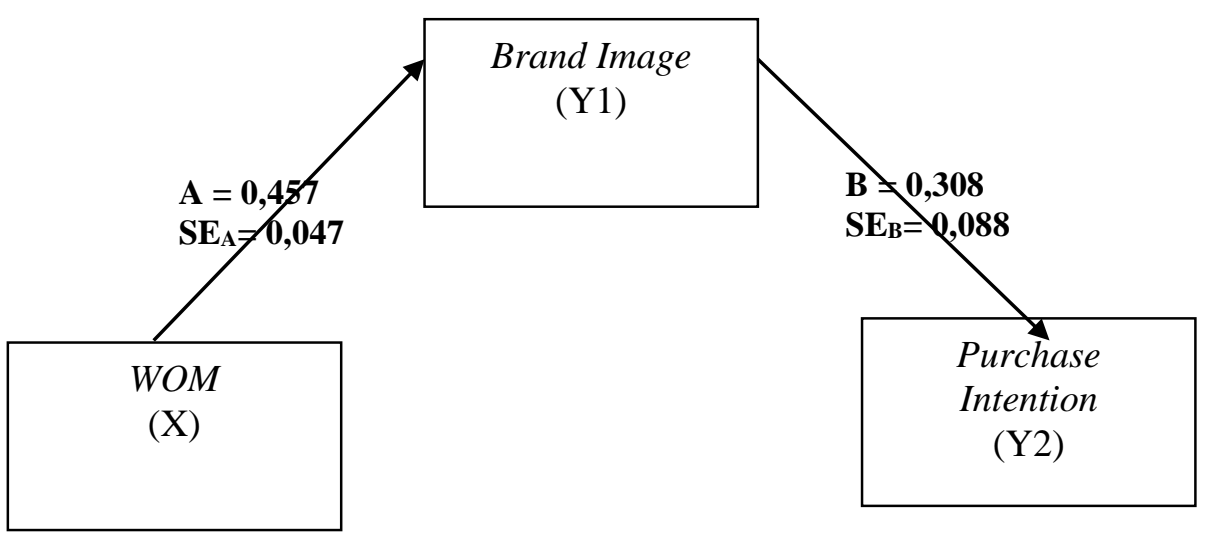

Gambar 1. WOM terhadap Purchase Intention melalui Brand Image

Tabel 6. Hasil Uji Sobel

\begin{tabular}{llccc}
\hline \multicolumn{1}{c}{ Jalur } & $\begin{array}{c}\text { Standardized } \\
\text { Coefficients }\end{array}$ & Standard Error & $\begin{array}{c}\text { Sobel test } \\
\text { statistic }\end{array}$ & $\begin{array}{c}\text { probabilitas } \\
\text { (uji 2 sisi) }\end{array}$ \\
\cline { 1 - 3 } $\mathrm{X} \rightarrow \mathrm{Y} 1$ & $\mathrm{~A}=0,457$ & $\mathrm{SE}_{\mathrm{A}}=0,047$ & & \\
\cline { 1 - 3 } $\mathrm{Y} 1 \rightarrow \mathrm{Y} 2$ & $\mathrm{~B}=0,308$ & $\mathrm{SE}_{\mathrm{B}}=0,088$ & & 0,000 \\
\cline { 1 - 3 } & & &
\end{tabular}

Sumber : Data primer diolah, 2020

Hasil uji Sobel menunjukkan nilai $t_{\text {hitung }}(3,342)>t_{\text {tabel }}(2,000)$ dan $p$ value (probabilitas uji dua sisi) $0,000<0,05$. Hasil ini menunjukkan, bahwa WOM berpengaruh signifikan terhadap purchase intention yang dimediasi brand image pada konsumen Mie Gacoan Surakarta. Dengan demikian hipotesis 4 diterima.

\section{PEMBAHASAN}

1. Pengaruh WOM terhadap Purchase Intention

Hasil pengujian hipotesis 1 menunjukkan bahwa WOM berpengaruh signifikan terhadap purchase intention pada konsumen Mie Gacoan Surakarta. Implikasi dari temuan ini, WOM positif yang semakin tinggi akan meningkatkan minat beli pada konsumen Mie Gacoan Surakarta. Berdasarkan hasil temuan ini, word of mouth adalah (WOM) yang terbentuk dari konsumen dapat berupa WOM positif atau WOM negatif. WOM positif dalam pembelian produk Mie Gacoan Surakarta merupakan informasi atau komentar yang positif dari konsumen, yang dapat 
mempengaruhi minat konsumen untuk membeli. Apabila konsumen memperoleh informasi yang baik atau positif tentang produk atau perusahaan Mie Gacoan Surakarta, maka akan membuat konsumen semakin tertarik untuk membeli, sehingga dapat mendorong minat beli konsumen.

Temuan penelitian ini mendukung penelitian yang dilakukan oleh Jalilvand (2012), Khan et al. (2015), Aditya dan Wardana (2017) bahwa WOM memiliki hubungan positif dan signifikan terhadap minat beli. Hasil penelitian ini juga mendukung temuan penelitian Akbar dan Rosita (2017); Khan et al. (2015); Tien (2018); Dewi dan Ardani (2018) bahwa WOM berpengaruh positif dan signifikan terhadap minat beli konsumen.

2. Pengaruh WOM terhadap Brand Image

Hasil pengujian hipotesis 2 menunjukkan bahwa WOM berpengaruh signifikan terhadap brand image pada konsumen Mie Gacoan Surakarta. Implikasi dari temuan ini, WOM positif yang semakin tinggi akan meningkatkan citra merek (brand image) Mie Gacoan Surakarta. Perusahaan dalam hal ini Mie Gacoan Surakarta perlu meningkatkan komunikasi pemasaran salah satunya dengan menginformasikan ulasan dan komentar positif dari konsumen. Ulasan dan komentar positif tersebut merupakan referensi penting bagi pemasar karena dapat membangun citra positif merek tokopedia. Apabila ulasan dan komentar positif konsumen semakin tinggi, artinya konsumen akan semakin yakin dengan merek Mie Gacoan, dan hal ini akan meningkatkan citra merek Mie Gacoan Surakarta.

Temuan ini mendukung penelitian yang pernah dilakukan oleh Torlak et al. (2014) bahwa electronic word of mouth (e-WOM) berpengaruh signifikan terhadap brand image. Ulasan atau kesan positif yang dilakukan konsumen dalam pembelian online dapat membangun citra positif merek, sehingga WOM menjadi informasi penting bagi para pemasar.

3. Pengaruh Brand Image terhadap Purchase Intention

Hasil pengujian hipotesis 3 menunjukkan bahwa brand image berpengaruh signifikan terhadap purchase intention pada konsumen Mie Gacoan Surakarta. Implikasi dari temuan ini, citra merek Mie Gacoan yang semakin kuat akan mempengaruhi tingginya minat beli konsumen. Brand image Mie Gacoan Surakarta menurut persepsi konsumen adalah rumah makan aneka mie di Surakarta yang memiliki merek yang baik. Indikatornya, produk yang dijual rumah makan Mie Gacoan Surakarta memiliki citra yang baik, produk yang dijual berbeda dengan merek lain, merek Mie Gacoan Surakarta telah dikenal oleh masyarakat luas, dan sebagian konsumen menyukai merek Mie Gacoan Surakarta karena reputasinya baik.

Hasil penelitian ini mendukung temuan sebelumnya yang dilakukan oleh Torlak et al. (2014) dan Yunus et al. (2016) menunjukkan bahwa brand image berpengaruh positif dan signfikan terhadap purchace intention. Temuan ini juga mendukung hasil penelitian sebelumnya yang dilakukan oleh Dewi dan Ardani (2018); Andrew (2019) bahwa terdapat pengaruh positif brand image terhadap purchace intention. Konsumen akan lebih berminat membeli produk atau jasa yang memiliki citra merek yang baik.

4. Pengaruh WOM terhadap Purchase Intention yang dimediasi Brand Image

Hasil pengujian hipotesis 4 menunjukkan bahwa WOM berpengaruh signifikan terhadap purchase intention yang dimediasi brand image pada konsumen Mie Gacoan Surakarta. Implikasi dari temuan ini, minat beli (purchase intention) dapat terjadi karena sebelumnya konsumen merasa yakin dengan citra merek (brand image) Mie Gacoan Surakarta, dan keyakinan terhadap brand image tersebut terbentuk karena adanya WOM positif yaitu ulasan dan komentar positif mengenai Mie Gacoan Surakarta.

Berdasarkan temuan ini, WOM adalah informasi atau komentar positif atau negatif dari konsumen tentang produk Mie Gacoan Surakarta melalui komunikasi langsung atau melalui media. Brand image adalah sejumlah keyakinan tentang merek Mie Gacoan Surakarta yang dipersepsikan oleh konsumen. Penilaian responden terhadap brand image diukur atas empat indikator yaitu citra positif merek Mie Gacoan, merek Mie Gacoan Surakarta memiliki ciri khas yang berbeda, merek Mie Gacoan Surakarta dikenal masyarakat luas, dan konsumen menyukai merek Mie Gacoan Surakarta.

Hasil penelitian sebelumnya, menunjukkan bahwa WOM berpengaruh terhadap purchace intention yang dimediasi oleh brand image. Hal ini didukung riset sebelumnya yang dilakukan oleh Torlak et al. (2014); Dewi dan Ardani (2018) dan Yunus et al. (2016). Hubungan dari ketiga variabel tersebut menunjukkan bahwa WOM dapat mempengaruhi brand image, dan selanjutnya 
brand image mempengaruhi purchace intention.

Hasil penelitian ini sejalan dengan penelitian yang dilakukan oleh Torlak et al. (2014) bahwa WOM berpengaruh terhadap purchase intention yang dimediasi brand image pada konsumen remaja di Turkey. Hasil penelitian ini ini juga mendukung penelitian Dewi dan Ardani (2018) bahwa brand image mampu menjadi variabel mediasi pada pengaruh word of mouth terhadap purchase intention pada pembelian produk Mie Samyang Hot Spicy Chicken di Kota Denpasar. Temuan ini juga sejalan dengan penelitian yang dilakukan oleh Yunus et al. (2016) bahwa pengaruh WOM terhadap purchase intention dimediasi oleh brand image pada konsumen yang membeli produk di media sosial Malaysia.

\section{PENUTUP}

\section{Kesimpulan}

Kesimpulan dari hasil penelitian ini (1) WOM berpengaruh signifikan terhadap brand image. (2) WOM berpengaruh signifikan terhadap purchase intention. (3) Brand image berpengaruh signifikan terhadap purchase intention. (4) WOM berpengaruh signifikan terhadap purchase intention yang dimediasi brand image. Temuan ini dapat digunakan sebagai kebijakan perusahaan khususnya pengusaha rumah makan Mie Gacoan Surakarta dalam upaya meningkatkan minat beli konsumen. Langkah-langkah strategis yang harus dilakukan dimulai dengan membangun WOM positif sehingga konsumen dapat menyebarluaskan keunggulan produk dan pelayanan dari perusahaan. Dengan terbentuknya WOM positif akan dapat membentuk citra merek Mie Gacoan semakin kuat, sehingga akan meningkatkan keyakinan konsumen terhadap merek dan selanjutnya akan mendorong minat konsumen untuk membeli. Perusahaan dalam hal ini rumah makan Mie Gacoan Surakarta hendaknya mempertahankan bahkan untuk terus meningkatkan brand image sebagai rumah makan spesial Mie yang terpercaya di kota Surakarta.

\section{DAFTAR PUSTAKA}

Aditya, Kadek Yoga dan I Made Wardana. (2017). Peran Brand Equity Dalam Memediasi Pengaruh Word of mouth Terhadap Purchase intention. E-Jurnal Manajemen Unud, 6 (2), 830-856.

Akbar, I. dan Rosita, N.H. (2017). Pengaruh Electronic Word of mouth dan Brand Image Terhadap Minat Pembelian Music Streaming JOOX. Jurnal Ilmiah Mahasiswa Fakultas Ekonomi dan Bisnis Brawijaya, 2 (5),1-17.

Andrew, Muhammad. (2019). E-Service Quality and Brand Image on Buying Interest: A Study of EService Quality and Brand Image on Shopee. Jurnal Sekretaris \& Administrasi Bisnis. 3(1). 23 28.

Arikunto, Suharsimi. (2006), Prosedur Penelitian, Edisi Revisi VI, Rineka Cipta, Jakarta.

Chang, C., \& Chin, Y. (2010). The Impact of Recommendation Sources on Online Purchase Intentions: The Moderating Effects of Gender and Perceived Risk. World Academy of Science, Engineering and Technology, 42(6), 111-114.

Jalilvand, M. R., and Samiei, N., 2012, The effect of electronic word of mouth on brand image and purchase intention An empirical study in the automobile. Marketing Intelligence and Planning, $30(4), 460-476$.

Khan, S. A., Ramzan, N., Shoaib, M., and Mohyuddin, A. (2015). Impact of Word of mouth on consumer purchase intention. Journal of Business and Management University of Engineering and Technology, 18 (21), 78-88.

Khuong, M. N. and Phuong, N T. (2017). The Effects of Destination Image, Perceived Value, and Service Quality on Tourist Satisfaction and Word-of-Mouth - A Study in Ho Chi Minh City, Vietnam. International Journal of Trade, Economics and Finance, 8(5). 217-224. 
Kotler, P. dan Amstrong, G. (2012). Prinsip-prinsip Pemasaran. Edisi 13 Jilid 1. Erlangga, Jakarta.

Kotler, P., \& Keller, K. (2009). Manajemen Pemasaran. Alih Bahasa Bob Sabran. Edisi 13, jilid 2. PT. Indeks. Jakarta

Lee, J., Park, D.-H., \& Han, I. (2008). The effect of negative online consumer reviews on product attitude: An information processing view. Electronic Commerce Research and Applications, 7(3), 341-352.

Nugraha, D.R.A., dan Saputri, M.E. (2018). The Effect of Product Quality and Word Of Mouth on Buying Interest in Chicken Dey. e-Proceeding of Management. 5(3). 3930-3937.

Rangkuti, F. (2006). Measuring Costumer Satisfaction (Teknik Mengukur dan Strategi Meningkatkan Kepuasan pelanggan). Gramedia Pustaka Utama. Jakarta.

Rangkuty, Freddy. (2008). The Power of Brand, Teknik Mengelola Brand Equity dan Strategy Perluasan Merek. Gramedia, Jakarta.

Rumambi, L. J., dan Siswanto, W. (2013). Dampak Environmental Advertising Melalui Iklan Televisi Terhadap Minat Beli Produk Elektronik AC Inverter Panasonic pada Calon Konsumen di Surabaya. Jurnal Manajemen Pemasaran. 1(1). 1-11.

Semuel, H., dan Lianto, A. S. (2014). Analisis e-WOM , Brand Image, Brand Trust Dan Minat Beli. Jurnal Manajemen Pemasaran, 8(2). 47-54.

Sher, P. J., \& Lee, S.H. (2009). Consumer Skepticism and Online Reviews: An Elaboration Likelihood Model Perspective. Journal of Social Behavior and Personality, 37(1), 137-143.

Shimp, Terence A. (2014). Intergrated Marketing Communication in Advertising and Promotion. Penerjemah: Harya Bhima Sena, Fitri Santi, dan Annisa Puspita Dewi. Salemba Empat. Jakarta.

Tien, D.H., Rivas, A.A., and Liao, Y.K. (2018). Examining the influence of customer-to-customer electronic word-of-mouth on purchase intention in social networking sites. Asia Pacific Management Review, xxx-2018, 1-12

Torlak, O., Ozkara, B.Y., Tiltay, M.A., Cengiz, H., and Dulger, M.F. (2014). The Effect of Electronic Word of Mouth on Brand Image and Purchase Intention: An Application Concerning Cell Phone Brands for Youth Consumers in Turkey. Journal of Marketing Development and Competitiveness. 8(2). 61-68.

Umar, Husein. (2009). Metodologi Penelitian Aplikasi dalam Pemasaran. Gramedia Pustaka Utama. Jakarta.

Yunus, N.H., Ariff, M.S., Som, N.M., Zakuan, N., and Sulaiman, Z. (2016). The Mediating Effect of Brand Image between Electronic Word of Mouth and Purchase Intention in Social Media. Advanced Science Letters. 22(10). 3176-3180. 